\title{
Identifikasi Potensi Interaksi Obat pada Peresepan Pasien Rawat Jalan Diabetes Melitus Tipe 2 dengan Hipertensi di RSUD dr. Soediran Mangun Sumarso Wonogiri
}

\section{Potency Identification or Drug Interaction in Prescribing Type 2 Diabetes Mellitus with Hypertension in Outpatient in RSUD dr. Soediran Mangun Sumarso Wonogiri}

\author{
Isna Syahrullah Murwati ${ }^{1}$, Lusia Murtisiwi ${ }^{1}$ \\ isnasyahrul@gmail.com, lusia.murtisiwi@stikesnas.ac.id \\ ${ }^{1}$ Sekolah Tinggi Ilmu Kesehatan Nasional, Surakarta \\ Riwayat Artikel: Dikirim Desember 2020; Diterima Februari 2021; Diterbitkan Maret 2021
}

\begin{abstract}
Abstrak
Penelitian ini bertujuan untuk mengetahui pola peresepan pasien diabetes melitus tipe 2 dengan hipertensi meliputi golongan dan jenis obat yang diresepkan, serta potensi terjadinya interaksi obat secara teoritik, berdasarkan mekanisme interaksi obat di instalasi rawat jalan RSUD dr. Soediran Mangun Sumarso Wonogiri tahun 2018. Penelitian ini merupakan penelitian non-eksperimental dengan rancangan penelitian deskriptif retrospektif. Hasil pengumpulan data rekam medis pasien periode Januari-Juni 2018 diidentifikasi berdasar literatur dan diolah dengan menghitung persentasenya. Golongan obat yang paling banyak digunakan adalah sulfonilurea $(19,64 \%)$ dan golongan obat hipertensi adalah ARB $(19,03 \%)$. Jenis obat diabetes yang paling banyak digunakan adalah glimepirid $(17,33 \%)$ dan hipertensi adalah irbesartan $(17,21 \%)$. Persentase hasil identifikasi interaksi obat secara teoritik adalah $62 \%(106)$ pasien, jenis interaksi obat yang paling banyak terjadi adalah interaksi farmakodinamik $64,5 \%$.
\end{abstract}

Kata Kunci : peresepan, farmakodinamik, interaksi obat

\begin{abstract}
This study aims to determine the prescription profile of diabetes mellitus type 2 with hypertension include classes and types of drugs and the potential of drug interactions theoretically, based on the mechanism drug interactions in outpatient installation of RSUD dr. Soediran Mangun Sumarso Wonogiri 2018. This research is a non-experimental study with descriptive retrospective. The data collected from medical records of patients between period January-June 2018 are identified based on the literature and processed by calculating the percentage. Class of diabetes drugs most widely used is a sulfonylurea $(19,64 \%)$ and hypertension drug classes ARB $(19,03 \%)$. Types of diabetic drugs most widely used was glimepirid $(17,33 \%)$ and hypertension was irbesartan $(17,21 \%)$. The percentage result of drug interactions theoretically was $62 \%$ (106 patiens), drug interactions type that the most occured was pharmacodynamic interactions $64,5 \%$.
\end{abstract}

Keywords : prescribes, pharmacodinamic, drug interaction 


\section{Pendahuluan}

Diabetes melitus merupakan kelompok penyakit metabolik yang ditandai dengan hiperglikemia, yaitu kondisi medik di mana kadar gula darah melebihi batas normal. Menurut penelitian Cho, dkk., (2018) dalam Diabetes Research and Clinical Practice pada tahun 2017 tercatat 451 juta orang dewasa dengan diabetes di dunia. Jumlah tersebut diprediksi akan meningkat menjadi 693 juta pada tahun 2045. Menurut International Diabetes Federation (IDF), pada tahun 2017 di Asia Tenggara jumlah orang dengan diabetes tercatat sebesar 84 juta dan diprediksi meningkat sekitar 84\% menjadi 156 juta pada tahun 2045 (IDF Atlas, 2017). WHO menyatakan prevalensi orang dengan diabetes di Indonesia mengalami kecenderungan peningkatan dari 5,7\% pada tahun 2007 menjadi 6,9\% pada tahun 2013 (WHO, 2016). Menurut Perkumpulan Endokrinologi Indonesia (PERKENI) 2015, estimasi laju peningkatan penderita diabetes melitus sebesar 2-3 kali lipat pada tahun 2035.

Departemen Kesehatan melalui laporan hasil Riskesdas 2018 menunjukkan prevalensi tertinggi diabetes melitus di Indonesia berdasar diagnosis dokter pada penduduk $\geq 15$ tahun di Jawa Tengah adalah sebesar 2,1\%. Prevalensi tertinggi diabetes melitus pada semua umur terdapat di Daerah Khusus Ibukota (2,8\%), sedangkan Jawa Tengah sebesar 1,6\%, dengan rincian toleransi gula terganggu (TGT) 30,8\%, dan glukosa darah puasa (GDP) terganggu sebesar 26,3\%. Dari penelitian Budhisusetyo (2012) pada bulan Maret 2011 didapatkan 30 pasien diabetes melitus telah melakukan kunjungan ulang dengan pemeriksaan GDP dan GDPP masih diatas normal sebanyak 83\%. Di antara 83\% pasien tersebut ditemukan 52\% mengalami hipertensi. Jumlah kunjungan pasien rawat jalan diabetes melitus dengan hipertensi di poklinik penyakit dalam RSUD dr. Soediran Mangun Sumarso Wonogiri tercatat sebanyak 314 pasien pada tahun 2016, dan mengalami kenaikan pada tahun 2017 menjadi 418 pasien.

Penderita diabetes melitus umumnya memerlukan obat lain untuk terapi penyakit penyerta yang dideritanya. Dalam kondisi seperti ini, tidak jarang pasien membutuhkan terapi lebih dari satu macam obat. Semakin banyak penggunaan obat, semakin besar kemungkinan efek samping yang terjadi atau dapat terjadi interaksi obat yang tidak dikehendaki. Interaksi obat merupakan salah satu faktor yang mempengaruhi respon tubuh terhadap pengobatan, yang dianggap penting secara klinis jika mengakibatkan peningkatan toksisitas dan atau berkurangnya efektivitas obat sehingga terjadi perubahan efek terapi (Setiawati, 2016). Berdasar uraian latar belakang tersebut, perlu dilakukan penelitian dengan tujuan untuk mengetahui persentase potensi terjadinya interaksi obat pada peresepan pasien rawat jalan diabetes melitus tipe 2 dengan hipertensi di poliklinik penyakit dalam RSUD dr. Soediran Mangun Sumarso Wonogiri.

\section{Metode Penelitian}

Penelitian ini merupakan penelitian non eksperimental dengan rancangan analisis deskriptif. Pengumpulan data dilakukan secara retrospektif melalui penelusuran catatan rekam medik pasien diabetes melitus tipe 2 dengan hipertensi di poliklinik penyakit dalam RSUD dr. Soediran Mangun Sumarso Wonogiri periode Januari- Juni 2018. Penelitian dilakukan di RSUD dr. Soediran Mangun Sumarso Wonogiri, pada bulan November sampai dengan Desember 2018. Populasi penelitian ini adalah pasien rawat jalan diabetes melitus tipe 2 dengan hipertensi, yang tercatat pada lembar rekam medik di poliklinik penyakit dalam RSUD dr. Soediran Mangun Sumarso Wonogiri periode Januari-Juni 2018 sebanyak 291 pasien. Sampel yang digunakan adalah sebagian dari populasi yang memenuhi kriteria inklusi dan eksklusi. Kriteria inklusi dari penelitian ini adalah: Pasien rawat jalan diabetes melitus tipe 2 dengan hipertensi, berumur 18-59 tahun di poliklinik penyakit dalam RSUD dr. Soediran Mangun Sumarso Wonogiri yang menerima sedikitnya satu jenis obat anti diabetika oral dan satu jenis obat antihipertensi, selama periode Januari-Juni 2018, sedangkan kriteria eksklusi penelitian ini adalah rekam medis pasien yang rusak sehingga tidak terbaca dan pasien yang hanya menerima resep insulin sebagai terapi antidiabetik disamping obat lainnya. Sampel dihitung menggunakan rumus dari Notoatmojo (2002), di mana jumlah populasi lebih kecil dari 10.000 yaitu :

Keterangan:

$$
n=\frac{N}{1+N\left(d^{2}\right)}
$$

$\mathrm{n}=$ Besar sampel yang diambil

$\mathrm{N}=$ Besar populasi

$\mathrm{d}=$ Derajat penyimpangan terhadap populasi yang diinginkan $5 \%(0,05)$ 
Jumlah pasien rawat jalan diabetes melitus tipe 2 dengan hipertensi di poliklinik penyakit dalam RSUD dr. Soediran Mangun Sumarso Wonogiri periode Januari-Juni 2018 sebesar 291 pasien. Maka besarnya sampel minimal dalam penelitian ini adalah 168 pasien.

\section{Analisis Data}

Analisis data dilakukan secara deskriptif dengan pengambilan data secara retrospektif kemudian data dipindahkan ke lembar pengumpulan data penelitian. Data penelitian yang diperoleh dari rekam medik RSUD dr. Soediran Mangun Sumarso Wonogiri periode Januari-Juni 2018 kemudian dianalisis secara deskriptif, yaitu:

1. Karakteristik pasien diabetes melitus tipe 2 dengan hipertensi

Karakteristik pasien diabetes melitus tipe 2 dengan hipertensi dihitung berdasarkan jenis kelamin, umur, kemudian dianalisis melalui jumlah dan persentase dan disajikan dalam bentuk tabel.

a) Persentase jenis kelamin pasien

$$
\begin{aligned}
& \% \\
& =\frac{\text { Jumlah pasien menurut jenis kelamin }}{\text { Jumlah semua sampel }} \times 100 \%
\end{aligned}
$$

b) Persentase umur pasien

$$
\%=\frac{\text { Jumlah pasien menurut umur }}{\text { Jumlah semua sampel }} \times 100 \%
$$

2. Pola peresepan pasien diabetes melitus tipe 2 dengan hipertensi

Pola peresepan pasien diabetes melitus tipe 2 dengan hipertensi meliputi golongan obat, jenis obat, dan jumlah obat antidiabetika dan antihipertensi yang digunakan dalam pengobatan pasien rawat jalan di RSUD dr. Soediran Mangun Sumarso Wonogiri.
3. Identifikasi interaksi obat

Identifikasi interaksi obat dihitung berdasar jumlah interaksi yang terjadi, kemudian dianalisis berdasar jenis mekanisme interaksi, disajikan dalam bentuk persentase.

a) Persentase jumlah interaksi yang terjadi $\%=\frac{\text { Jumlah interaksi yang terjadi }}{\text { Jumlah semua sampel }} \times 100 \%$

b) Persentase jumlah jenis interaksi yang terjadi

$$
\%=\frac{\text { Jumlah interaksi yang terjadi }}{\text { Jumlah semua sampel }} \times 100 \%
$$

\section{Hasil dan Pembahasan}

Analisis secara deskriptif dilakukan untuk mengetahui karakteristik pasien, pola peresepan pasien diabetes melitus tipe 2 dengan hipertensi, persentase jumlah jenis interaksi yang terjadi, dan persentase jumlah jenis interaksi yang terjadi. Sampel yang dipilih sebanyak 170 pasien dari total populasi 291 pasien.

\section{Karakteristik Pasien Diabetes Melitus tipe 2 dengan Hipertensi}

Penyakit diabetes melitus tipe 2 dengan hipertensi di RSUD dr. Soediran Mangun Sumarso lebih banyak disandang pasien berjenis kelamin perempuan $(73 \%)$ dibanding laki-laki (27\%). Paling banyak diderita pasien berumur 46-55 tahun yaitu sebanyak 96 orang $(56,47 \%)$ sedangkan paling sedikit terjadi pada umur 2635 tahun yaitu sebanyak 2 orang $(1,18 \%)$. 
Tabel 1. Data golongan obat pada peresepan pasien diabetes melitus tipe 2 dengan hipertensi di RSUD dr. Soediran Mangun Sumarso Wonogiri

\begin{tabular}{|c|c|c|c|}
\hline Obat & Golongan Obat & Jumlah & $\%$ \\
\hline \multirow{5}{*}{ Diabetes Melitus } & Sulfonilurea & 162 & \\
\hline & Biguanida & 77 & \\
\hline & Inhibitor alfa glukosidase & 7 & 36,60 \\
\hline & Thiazolidinedione & 3 & \\
\hline & Insulin & 53 & \\
\hline \multirow[t]{5}{*}{ Hipertensi } & ACE inhibitor & 2 & \\
\hline & Antagonis kalsium & 101 & \\
\hline & Beta bloker & 26 & 36,96 \\
\hline & Loop diuretik & 19 & \\
\hline & $\mathrm{ARB}$ & 157 & \\
\hline \multirow[t]{20}{*}{ Obat lain } & Antasida & 2 & \\
\hline & Vitamin & 63 & \\
\hline & Antivertigo & 6 & \\
\hline & Analgetik & 5 & \\
\hline & Mukolitik & 4 & \\
\hline & PPP & 23 & \\
\hline & NSAID & 11 & \\
\hline & Antiulcerant & 10 & \\
\hline & Antikonvulsan & 62 & 26,42 \\
\hline & Benzodiazepin & 1 & \\
\hline & Vasodilator & 5 & \\
\hline & Antihiperurisemia & 1 & \\
\hline & Antihiperlipidemia & 3 & \\
\hline & Antihistamin & 2 & \\
\hline & Suplemen & 12 & \\
\hline & Hormon & 1 & \\
\hline & Antibiotik & 2 & \\
\hline & Antidepresan & 3 & \\
\hline & Digitalis & 1 & \\
\hline & Antiplatelet & 1 & \\
\hline Jumlah & & 825 & 100 \\
\hline
\end{tabular}

Keterangan:

ARB (Angiotensin Reseptor Blocker)

NSAID (Non Steroid Anti Inflamasi Drug)

PPP (Penghambat Pompa Proton)

Tabel 2. Jenis obat yang digunakan pada peresepan pasien diabetes melitus tipe 2 dengan hipertensi di RSUD dr. Soediran Mangun Sumarso Wonogiri

\begin{tabular}{cccc}
\hline Golongan Obat & Jenis Obat & Jumlah & $\%$ \\
\hline Sulfonilurea & Glimepirid & 143 & 17,33 \\
& Glicazide & 13 & 1,58 \\
& Gliquidone & 6 & 0,73 \\
\hline Biguanida & Metformin & 77 & 9,33 \\
\hline Inhibitor alfa glukosidase & Acarbose & 7 & 0,85 \\
\hline Tiazolinidinedione & Pioglitazone & 3 & 0,36 \\
\hline Insulin & Insulin Aspart & 36 & 4,36 \\
& Insulin Glargine & 13 & 1,58 \\
& Insulin Lispro & 3 & 0,36 \\
& Insulin Gluisine & 1 & 0,12 \\
\hline ACE inhibitor & Imidapril & 2 & 0,24 \\
\hline
\end{tabular}




\begin{tabular}{|c|c|c|c|}
\hline Golongan Obat & Jenis Obat & Jumlah & $\%$ \\
\hline \multirow[t]{3}{*}{ Antagonis kalsium } & Amlodipin & 81 & 9,82 \\
\hline & Nifedipin & 18 & 2,18 \\
\hline & Diltiazem & 2 & 0,24 \\
\hline \multirow[t]{2}{*}{ Beta bloker } & Bisoprolol & 25 & 3,03 \\
\hline & Propanolol & 1 & 0,12 \\
\hline Loop diuretik & Furosemid & 19 & 2,3 \\
\hline \multirow[t]{2}{*}{$\mathrm{ARB}$} & Candesartan & 15 & 1,82 \\
\hline & Irbesartan & 142 & 17,21 \\
\hline \multirow[t]{2}{*}{ Antasida } & Antasid syr & 1 & 0,12 \\
\hline & Rebamipid & 1 & 0,12 \\
\hline \multirow[t]{2}{*}{ Vitamin } & Vitamin B1, B6, B12 & 31 & 3,76 \\
\hline & Mecobalamin & 32 & 3,88 \\
\hline \multirow[t]{4}{*}{ Suplemen } & Potasium klorida & 3 & 0,36 \\
\hline & Glucosamin & 3 & 0,36 \\
\hline & Amino keto acid & 5 & 0,61 \\
\hline & Ursodeoxyholic acid & 1 & 0,12 \\
\hline \multirow[t]{2}{*}{ Antivertigo } & Flunarizin & 2 & 0,24 \\
\hline & Betahistin & 4 & 0,48 \\
\hline Analgetik & Parasetamol & 5 & 0,61 \\
\hline \multirow[t]{3}{*}{ Mukolitik } & Acetylsystein & 1 & 0,12 \\
\hline & Ambroxol & 2 & 0,24 \\
\hline & OBH syrup & 1 & 0,12 \\
\hline Antikonvulsan & Gabapentin & 62 & 7,52 \\
\hline \multirow[t]{2}{*}{ PPP } & Omeprazol & 2 & 0,24 \\
\hline & Lansoprazole & 21 & 2,55 \\
\hline \multirow[t]{2}{*}{ NSAID } & Meloxicam & 10 & 1,21 \\
\hline & Na. Diklofenak & 1 & 0,12 \\
\hline Antiulcerant & Sucralfat & 10 & 1,21 \\
\hline Benzodiazepin & Diazepam & 1 & 0,12 \\
\hline \multirow[t]{2}{*}{ Vasodilator } & Isosorbid dinitrat & 4 & 0,48 \\
\hline & Glyseryl trinitrat & 1 & 0,12 \\
\hline Antihiperurisemia & Allopurinol & 1 & 0,12 \\
\hline \multirow[t]{2}{*}{ Antihiperlipidemia } & Simvastatin & 2 & 0,24 \\
\hline & Gemfibrozil & 1 & 0,12 \\
\hline Antihistamin & Cetirizin & 2 & 0,24 \\
\hline Antiplatetlet & Clopidrogel & 1 & 0,12 \\
\hline \multirow[t]{2}{*}{ Antibiotik } & Cefixim & 1 & 0,12 \\
\hline & Cefadroxil & 1 & 0,12 \\
\hline Hormon & Thyrozol & 1 & 0,12 \\
\hline Antidepresan & Amitriptyllin & 3 & 0,36 \\
\hline Digitalis & Digoxin & 1 & 0,12 \\
\hline \multicolumn{2}{|c|}{ Total } & 825 & 100 \\
\hline
\end{tabular}

\section{Keterangan:}

ARB (Angiotensin Reseptor Blocker)

NSAID (Non Steroid Anti Inflamasi Drug)

PPP (Penghambat Pompa Proton) 


\section{Pola peresepan pasien diabetes melitus tipe 2 dengan hipertensi}

Pola peresepan pasien meliputi jumlah obat antidiabetika dan anti hipertensi, golongan obat antidiabetika dan antihipertensi, dan jenis obat antidiabetika dan antihipertensi. Data yang diperoleh disajikan dalam tabel 1 dan 2 .

Golongan obat antidiabetika yang paling banyak digunakan adalah sulfonilurea 19,64\% (162 obat) dengan jenis obat antidiabetika glimepirid 17,33\% (143 obat). Golongan obat anti hipertensi yang paling banyak digunakan adalah Angiotensin Reseptor Blocker (ARB) $19,03 \%$ (157 obat) dengan jenis obat antihipertensi irbesartan 17,21\% (142 obat). Irbesartan menghambat perubahan Angiotensin I menjadi Angiotensin II sehingga terjadi vasodilatasi dan penurunan sekresi aldosteron (Nafrialdi, 2016).

\section{Identifikasi potensi interaksi obat pada peresepan pasien diabetes melitus tipe 2 dengan hipertensi}

Identifikasi potensi interaksi obat pada peresepan pasien diabetes mellitus tipe 2 dengan hipertensi meliputi persentase potensi interaksi obat yang terjadi, persentase jumlah jenis interaksi obat yang terjadi. Dari 170 sampel penelitian sebanyak 106 pasien (62\%) berpotensi mengalami interaksi obat, dan 64 pasien $(38 \%)$ tidak berpotensi mengalami interaksi obat. Proporsi potensi interaksi obat yang terjadi dapat dilihat pada gambar 1 .

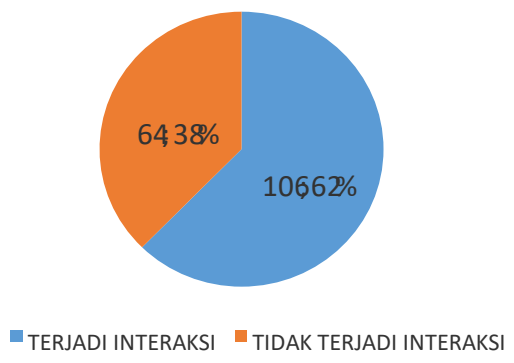

Gambar 1. Proporsi potensi interaksi obat

Analisis terhadap 106 pasien yang mengalami interaksi terdapat total potensi kejadian interaksi obat sebanyak 200 potensi yang terdiri dari $129(64,5 \%)$ interaksi farmakodinamik, sebanyak $36(18 \%)$ interaksi farmakokinetik, dan 35 (17,5\%) interaksi yang tidak diketahui (unknwon). Interaksi farmakodinamik terjadi pada tingkat reseptor dan mengakibatkan berubahnya efek salah satu obat, bersifat sinergis bila efeknya menguatkan atau antagonis bila efeknya mengurangi. Interaksi farmakodinamik sinergis yang terjadi di antaranya adalah interaksi antara glimepirid dan imidapril (ACE inhibitor), mengakibatkan peningkatan sementara sensitivitas insulin oleh ACE inhibitor (Tatro, 2009). Interaksi farmakodinamik antagonis di antaranya adalah interaksi antara meloxicam dan irbesartan, di mana meloxicam dapat menurunkan efek dari irbesartan. Interaksi antara furosemid dan potasium klorida merupakan interaksi farmakodinamik antagonis yang bertujuan menjaga kadar kalium dalam keadaan normal, di mana penggunaan furosemid dapat menurunkan kadar kalium, sehingga penggunaan potasium klorida dapat membantu mencegah penurunan kadar kalium. Interaksi farmakokinetik adalah interaksi yang terjadi apabila suatu obat mengubah absorbsi, distribusi, metabolisme dan ekskresi obat lain. Interaksi farmakokinetik yang diperoleh pada penelitian ini adalah interaksi antara metformin dan nifedipin, di mana nifedipin meningkatkan kadar metformin dengan meningkatkan absorbsi di usus, hanya berlaku jika sediaan berbentuk oral dari kedua obat (Medscape, 2018). Interaksi antara glimepirid dan gemfibrozil merupakan interaksi dengan mekanisme farmakokinetik di mana gemfibrozil meningkatkan efek glimepirid melalui kompetisi ikatan protein plasma sehingga menimbulkan risiko hipoglikemi (Medscape, 2018). Efek hipoglikemik dari glimepirid dapat meningkat dengan penghambatan metabolisme glimepirid (CYP2C9) oleh gemfibrozil (Tatro, 2009). Interaksi antara gabapentin dan mecobalamin merupakan interaksi farmakokinetik di mana gabapentin menurunkan kadar mecobalamin dengan meningkatkan absorbsi di usus, hanya berlaku untuk bentuk sediaan oral dari kedua obat (Medscape, 2018). 
Interaksi jenis unkown yang diperoleh pada penelitian ini adalah interaksi antara metformin dan mecobalamin, di mana metformin menurunkan kadar mecobalamin dengan mekanisme interaksi yang tidak spesifik (Medscape, 2018). Interaksi antara metformin dan furosemid dapat mengakibatkan penurunan kadar furosemid dengan mekanisme yang tidak diketahui (Medscape,
2018). Sucralfat menurunkan kadar lansoprazole dengan menghambat penyerapan di usus, hanya berlaku untuk sediaan oral. Interaksi ini dapat dihindarkan dengan memberi jarak penggunaan yaitu 2 jam sebelum makan untuk sucralfat, dan 4 jam setelah makan untuk lansoprazol (Ansari, 2010). Data identifikasi potensi interaksi obat selengkapnya dapat dilihat pada tabel 3

Tabel 3. Identifikasi potensi interaksi obat berdasar mekanisme interaksi

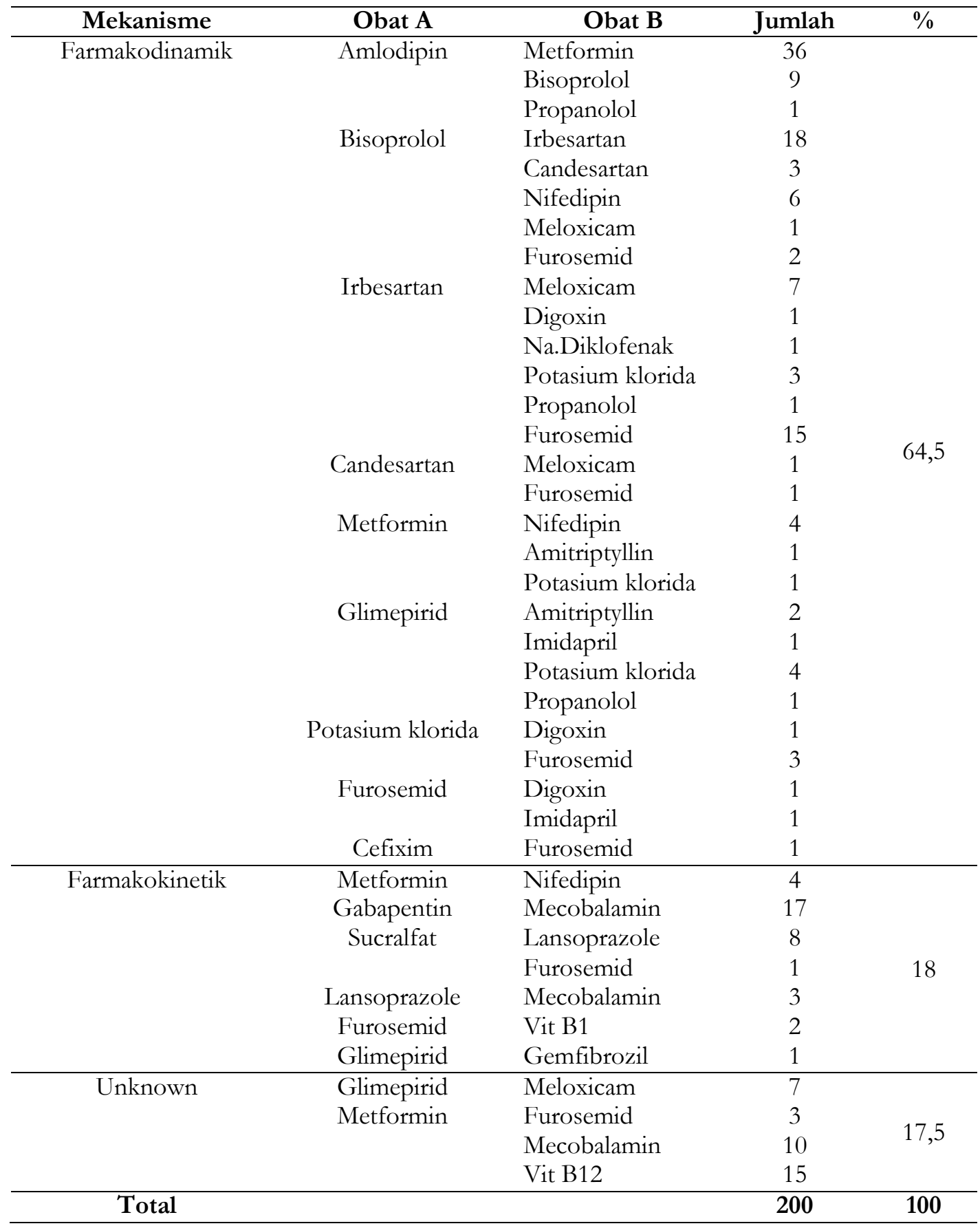




\section{Simpulan}

Penyakit diabetes melitus tipe 2 dengan hipertensi di RSUD dr. Soediran Mangun Sumarso lebih banyak disandang pasien berjenis kelamin perempuan (73\%) dibanding laki-laki (27\%). Paling banyak diderita pasien berumur 46-55 tahun yaitu sebanyak 96 orang $(56,47 \%)$ sedangkan paling sedikit terjadi pada umur 2635 tahun yaitu sebanyak 2 orang $(1,18 \%)$

Obat antidiabetika yang paling banyak digunakan adalah dari sulfonilurea yaitu 19,64\% dengan jenis obat yang paling banyak digunakan adalah glimepirid yaitu 17,33\%. Obat antihipertensi yang paling banyak digunakan adalah dari golongan ARB yaitu 19,03\% dengan jenis obat irbesartan yaitu 17,21\%.

Dari 170 sampel penelitian $62 \%$ diidentifikasi berpotensi terjadi interaksi obat dengan persentase jumlah jenis interaksi yang terjadi adalah interaksi farmakodinamik sebesar $64,5 \%$, interaksi farmakokinetik sebesar 18\% dan interaksi unknown sebesar 17,5\%.

\section{Ucapan Terima Kasih}

Terimakasih kami ucapkan kepada RSUD dr. Soediran Mangun Sumarso Wonogiri.

\section{Daftar Pustaka}

Ansari, JA. 2010. Drug Interaction and Pharmacist. New Delhi: Journal of Young Pharmacist Vol.2 No. 3

Budhisusetyo, P., 2012, Hubungan Antara Dukungan Keluarga Dengan Kepatuhan Diit Pada Pasien Diabetes Mellitus Tipe 2 Rawat Jalan di RSUD dr. Soediran Mangun Sumarso, Skripsi, Program Studi Ilmu Gizi Fakultas Ilmu Kesehatan Universitas Muhammadiyah, Surakarta.

Cho, N. H., Shaw, J. E., Karuranga, S., Huang, Y., da Rocha Fernandes, J. D., Ohlrogge

A. W., \& Malanda, B. 2018. IDF Diabetes Atlas: global estimates of diabetes prevalence for 2017 and projections for 2045. Diabetes research and clinical practice, 138, 271-281.
International Diabetes Federation. IDF Diabetes Atlas, 8th edn. Brussels, Belgium: International Diabetes Federation, 2017. http://www.diabetesatlas.org diakses pada 3 Oktober 2018.

Kemenkes RI, 2018, Riset Kesehatan Dasar: Riskesdas 2018. Jakarta: Badan Penelitian dan Pengembangan Kesehatan. Kementrian Kesehatan Re publik Indonesia.

Medscape, 2018, Drug Interaction Checker, https://reference.medscape.com/druginteractionchecker

Nafrialdi, 2016, Interaksi Obat. Dalam: Farmakologi dan Terapi, Edisi 6, Departemen Farmakologi dan Teraupetik, Fakultas Kedokteran Universitas Indonesia, Jakarta.

Notoatmodjo., 2002, Metodologi Penelitian Kesehatan (edisi revisi), PT. Rineka Cipta, Jakarta.

PERKENI, 2015, Konsensus Pengelolaan dan Pencegahan Diabetes Mellitus Tipe II di Indonesia, Perkumpulan Endrokrinologi Indonesia, Jakarta

Setiawati A, 2016, Interaksi Obat. Dalam: Farmakologi dan Terapi, Edisi 6, Departemen Farmakologi dan Teraupetik, Fakultas Kedokteran Universitas Indonesia, Jakarta.

Tatro D., 2009, Drug interaction Facts TM, editor : David S. Tatro, Fact and Comparisons, St. Louis, Missouri.

WHO, 2016, Diabetes Fakta dan Angka diakses dari http:/www.searo.who.int/indonesia/ topics/8-whd2016-diabetes-facts-andnumbers-indonesian pada 15 Nopember 2018. 